\title{
Exploring the facet of elderly care centre in multiethnic Malaysia
}

\author{
Filzah Md Isa and Shaista Noor
}

Faculty of Business, Taylor's University, Selangor Darul Ehsan, Malaysia

Goh Wei Wei

School of Computer Science and Engineering, Taylor's University, Selangor Darul Ehsan, Malaysia

Sharifah Diyana Binti Syed Hussain

Faculty of Business, Taylor's University,

Selangor Darul Ehsan, Malaysia

Hairunnisa Mohamad Ibrahim

Pre-University Studies, Taylors College, Selangor Darul Ehsan, Malaysia, and

Muhd Afiq Syazwan Ahmdon

Taylor's University, Selangor Darul Ehsan, Malaysia

\begin{abstract}
Purpose - Malaysia is considered to be a relatively young country as compared to other older countries such as Japan, China and Australia in terms of the ageing population. However, until 2035, Malaysia will be in the ageing group countries as 15\% of the entire population will be above 60 years of age. This situation is quite alarming as more and more ageing care centres will be required to fulfill the ongoing demands of the ageing population. The elderly care centres in Malaysia are categorised as public (sponsored by the government), private, and charity based that comes under religious centres. Currently, there are about 365 registered elderly care centres working in the main states of Malaysia, including Sabah and Sarawak, two states of the East Malaysia. Due to the importance of ageing population issues, the present study is conducted to explore the demographics facet of Malaysian's elderly care centres. The main reason behind that lies on the fact that many of these centres are still labelled as being not well equipped and lacking behind in trained staff, equipment and also suffering from severe financial constraints but some still capable of working on a sustainability basis.
\end{abstract}

Design/methodology/approach - Qualitative Research Strategy has been adopted, and 28 centres throughout Malaysia are included in this study. About 18 Operators from different centres and 15 caregivers were interviewed to get the holistic view of ageing care and facilities in their respective centres.

Findings - The results highlight that the majority of centres are not receiving any financial help from the government, and few centres are doing small business such as supplying consumable medical and non-

(C) Filzah Md Isa, Shaista Noor, Goh Wei Wei, Sharifah Diyana Binti Syed Hussain, Hairunnisa Mohamad Ibrahim and Muhd Afiq Syazwan Ahmdon. Published in PSU Research Review. Published by Emerald Publishing Limited. This article is published under the Creative Commons Attribution (CC BY 4.0) licence. Anyone may reproduce, distribute, translate and create derivative works of this article (for both commercial and non-commercial purposes), subject to full attribution to the original publication and authors. The full terms of this licence maybe seen at http:// creativecommons.org/licences/by/4.0/legalcode

Received 7 May 2020 Revised 13 August 2020 Accepted 16 September 2020 
PRR

6,1

18

medical items and providing renting and rehabilitation centres facilities to sustain. The caregivers are facing issues such as excess workload, less salary, peer conflicts and non-cooperative centre leadership.

Originality/value - The present study may help to provide useful information to the policymakers, which enables them to formulate the strategies for ageing care centres in Malaysia. As this study provides insight of components that have an impact on the overall wellbeing of elderly care centres, hence, it could help the care services providers to act as a rising star for Malaysian's social life comfort.

Keywords Ageing, Care centre, Caregivers, Operators, Malaysia

Paper type Research paper

\section{Introduction}

Ageing population is a worldwide phenomenon, and it affects all traits of human life. The ageing population has shown an evident rise in both developing and developed countries (Burton, 2016). A report highlights that until 2050, the world population will increase from 8 to 9.6 billion, and this will post a significant challenge in the countries all across the globe (Amiri, 2018), including Malaysia. The elderly people are expected to be tripled from the year 1980 (259 million) to year 2025 (761 million); while about $72 \%$ of the entire elderly population are residing in developing countries. Malaysia, a representative of a developing country, has been estimated to have about $5 \%$ of its entire population to be 60 years of age and above by year 2030 (Department of Statistics Malaysia, 2018). Undoubtedly, the ageing is a continuous process, and another report shows that until 2030, Malaysia will be in the same line of other ageing group countries e.g. Japan, USA and China (Phua et al., 2019; Rashid and Tahir, 2015). The ageing or older age is associated with changes in physical appearance such as wrinkled skin, grey hairs and physical decline (Normala et al., 2014; Zivin et al., 2013; Noor et al., 2020), which lead to certain medical issues such as hypertension, dementia, arthritis, respiratory diseases and neurological disorders. Thus, older population needs more health-care facilities and attention, and elderly care centres are considered the key players in promoting healthy ageing among the elderly segment.

In Malaysia, the elderly care centres are categorised as public, private, nongovernmental organisations (NGOs) and centres run by religious organisations and church community. The ageing population is increasing day by day with various elderly health issues, and children feel it is very challenging to take care of their elderly parents because of their busy routine and lifestyle. This led to a demand for more technological well-equipped elderly care centres in Malaysia along with the trained staff or professional care givers. Currently, about 365 registered elderly care centres are working in the main states of Malaysia, e.g. Klang Valley area, Johor and Penang (Phua et al., 2019), along with various unregistered centres scattered around the country. The estimated number implicates that Malaysia may require around 2,000 registered elderly care centre until 2030 to fulfil the requirements of the ageing population and to maintain an operational standard of elderly care centres throughout the country (Advance Care Planning, 2018). The elderly care centres' management is trying their best to fulfil the needs of the older population. However, many milestones need to be achieved, as many centres are still not well-equipped and facing issues related to finances, technology, staffing and others. Hence, the rationale of this study is to explore the demographics disguise of elderly care centres in Malaysia to disclose the obstacles facing by these centres as the centres' operators are the custodian for providing care, special attention and social life comfort to the older population of Malaysia. 


\section{Literature review}

The ageing population is rising across the globe, including Malaysia, thus, the older people are increasing in number than ever before as World Population Ageing (2019) reported that population of age 60 or above reaches to $10 \%$ of the total population in various countries, and counting them as an aged nation (Meriam Syed Akil and Abdullah, 2014; Samad and Mansor, 2017). Past research studies revealed two significant factors that involve in ageing population, namely, a decline in fertility rate and increased longevity because of improved health and medical services and increased technology and overall economic development Exploring the facet of elderly care centre (Forsyth and Chia, 2009; Selvaratnam et al., 2009; Ursulica, 2016). In line with longevity, Fahey (2003) stated that in more than 20 developing countries, life expectancy is about 72 years or above. From another view, an expected increase in the elderly percentage in Malaysia is from $6.3 \%$ (the year 2000) to $12.0 \%$ (4.9 million) in 2030. Even though the older population has shown an increase all across the world, the rate of change is higher in developing countries. In line with this, Keyes (2017) suggested that Malaysia, one of the developing countries in Association of Southeast Asian Nations region, is now becoming a nation progressing towards ageing; therefore, health-care needs and facilities of senior citizen are also in high demand. Research studies suggest that by the year 2025, the ageing population will reach around 1.2 billion (14\% of total population), and three-quarters of the elderly population will be residing in the developing countries (King et al., 2019). Keeping in view the alarming situation of the drastic increase of the elderly population in developing countries, Malaysia needs a proper planning for maintaining a healthy environment and care facilities for the elderly. The support and care that is provided in-home to elderly seems to be unable to fulfil the sensitive requirements of old age's chronic diseases (Soong, 2016). Subsequently, it leads to the increasing demand of elderly care centres. Table 1 shows the categorisation of registered elderly care centres in Malaysia.

Studies revealed that the registered elderly centres in Malaysia are still lagging in terms of modern set-up and technology usage (Phua et al., 2019; Noor et al., 2020). Similarly, in most of the centres, the facilities are not up to the mark and insecure because of obsolete equipment, lack of monitoring and repeated usage of installed machinery. These centres, however, are working on a sustainability basis without any profit-making, and sometimes the centres' operators have to borrow money for the next month budget settlements, and it is

\begin{tabular}{|c|c|c|c|}
\hline Sr. no. & Location (State) & No. of elderly care centres & \\
\hline 1 & Kedah & 13 & \\
\hline 2 & Perak & 62 & \\
\hline 3 & Selangor (most) & 86 & \\
\hline 4 & Kuala Lumpur & 28 & \\
\hline 5 & Terengganu & 2 & \\
\hline 6 & Negeri Sembilan & 22 & \\
\hline 7 & Melaka & 27 & \\
\hline 8 & Johor & 73 & \\
\hline 9 & Sabah & 8 & \\
\hline 10 & Pahang & 16 & \\
\hline 11 & Perlis (least) & 1 & \\
\hline 12 & Kuching, Sarawak & 10 & \\
\hline \multirow[t]{2}{*}{13} & Penang & 17 & \\
\hline & Total & 365 & $\begin{array}{l}\text { Table } 1 . \\
\text { derly care centres }\end{array}$ \\
\hline \multicolumn{3}{|c|}{ Source: www.agedcare.com.my/about/Malaysia (2018) } & in Malaysia \\
\hline
\end{tabular}


PRR

6,1

becoming one of the critical reason of stress among many centre operators (Samad and Mansor, 2017; Noor et al., 2019). The Malaysian Government does provide regular monetary incentives to all centres except only to those centres that directly come under the Ministry of Women, Family and Community Development agency supervision, whereas, privately owned centres are not getting any funding from the government. Therefore, the privateowned centres have to seek external funding on their own either in the form of donations or the creation of small business to generate some regular income (Vannucci and Weinstein, 2017). Irrespective, the services provided by most elderly care centres are still not sufficient and efficient in terms of technology and health services as the standardised operational manual that can benefit all elderly care centres is also lacking in Malaysia (Leng et al., 2016; Rashid and Tahir, 2015). There is a remarkable need for well-developed strategies regarding the needs of senior citizens and facilities in elderly care centres in Malaysia, as done in other Asian countries such as Japan and Singapore, for a healthy and graceful ageing segment.

\section{Research objective}

- To explore the demographics facet of elderly care centres in Malaysia.

- To determine the issues and challenges confronted by centre operators and caregivers.

\section{Research question}

- What is the current scenario of elderly care centres in Malaysia?

- What types of obstacles are confronted by centre operators and caregivers?

\section{Methodology}

Qualitative methodology is considered as the best approach to discover and explore a new area-developing hypothesis (Miles and Huberman, 1994). This study is exploratory research that involves a qualitative method of data collection by using the self-administered (Bradburn et al., 2004) and open-ended questionnaire. Several researchers suggested that exploratory research is useful for defining a set of investigative questions that can be used as a guide for detailed research design (Easterby-Smith et al., 1991). The present study considers the interpretive philosophical stance as interpretivism is associated with the experience of people. This philosophy concerns about individual's interaction with society (Creswell, 2003). The research design plays an important role and helps the researcher to answer the research question or put into entire scheme of research (Hall et al., 2016). To answer the objectives of the present research, explanatory research design is more appropriate as the study is exploratory in nature. Currently, around 365 registered ageing care centres are working in various states of Malaysia (Advance Care Planning, 2018; Phua et al., 2019). In this present study, 18 centre operators and 15 caregivers who are running the elderly care centres in several main states of Malaysia were interviewed. This number of samples is suggested by Creswell and Poth (2013) and Hall (2016). The present study adopted the purposive sampling technique to select the 18 centre operators and 15 caregivers from selected ageing care centres. The interviews were conducted in both English and Malay languages from April 2019 to December 2019. The duration of the interview lasted about $45 \mathrm{~min}$ to $1 \mathrm{~h}$. The interview questions prepared for semi-structured interviews corresponded to two categories, namely, operators and caregiver. Operators are the entrepreneurs who run the ageing care centre as a business entity, whereas care givers are those employees working in the centres to provide services to the elderly. The interview questions were specially designed to answer the research questions and objectives 
pertaining to elderly care centres, as highlighted in the literature review. Bryman and Bell (2007) stated that prolong questions should not be asked, and negative question need not be included in an interview guide. Similarly, technical language needs not be used as it is essential that the participant clearly understand the meaning of the asked questions. Saldana and Omasta (2016) introduced a seven-step technique, modified from Moustakas's (1994) method for a qualitative analysis, which adopted semi-structured questionnaires and audio-recorded interviews for data gathering. This method provides a systematic and organised way to analyse the collected data and used in various studies (Hall et al., 2016; Merriam, 2009). Below mentioned is the interview question asked from centre operators (Table 2) and centres caregivers (Table 3).

\section{Descriptive statistics}

Tables 4-7 show the profile of the operators as the research participants. The details depict that out of 18 participants, 4 belong to the age group 36-40 years, 5 belong to the age group 40-45 years, another 5 belong to the age group 25-31 years and the last 4 belong to age group 45 years and above. For the present study, 12 males and 6 females were interviewed. Regarding qualification, 12 participants have a diploma certification, 4 have a bachelor's degree while the remaining 2 have a master's degree. Most of the participants skewed towards Malay ethnicity (9), followed by Chinese (6), Indians (2) and (1) other nationality. Regarding year of establishment of centre, majority of the respondents (8) have been operating the centre for six to nineyears, followed by five respondents who operate the centre for three to six years and four running the centre for nine years or more. Table 4 exhibits the profile of interviewed participants.

Below are Tables 5 and 6 regarding demographic details of interviewed first group of participant centre operators. The table highlights that 13 of them are running the centre as the sole owner, and 5 are running under a group partnership. In line with this, all of the centres have caregiver, cook and supporting staff. Two of the centres (O1 and $\mathrm{O} 7$ ) have about 20-25 caregivers, and all of them have at least 1 medical doctor and support staff. The strength of the female elderly is more significant in the number in each centre as compared
Exploring the facet of elderly care centre

\section{care centre}

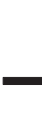




\begin{tabular}{|c|c|c|c|c|}
\hline \multirow{3}{*}{$\begin{array}{l}\text { PRR } \\
6,1\end{array}$} & \multirow[b]{2}{*}{ Sr. no. } & & & \\
\hline & & \multicolumn{2}{|c|}{ Variable } & \multirow{2}{*}{$\begin{array}{c}\text { No. of respondents } \\
\begin{array}{c}12 \\
6\end{array}\end{array}$} \\
\hline & 1 & Sex & $\begin{array}{l}\text { Male } \\
\text { Female }\end{array}$ & \\
\hline 22 & 2 & Age & $\begin{array}{l}25-31 \text { years } \\
36-40 \text { years } \\
40-45 \text { years } \\
45 \text { years onward }\end{array}$ & $\begin{array}{l}5 \\
4 \\
5 \\
4\end{array}$ \\
\hline & 3 & Education level & $\begin{array}{l}\text { Diploma } \\
\text { Bachelors } \\
\text { Masters } \\
\text { MPhil } \\
\text { PhD }\end{array}$ & $\begin{array}{r}12 \\
4 \\
2 \\
0 \\
0\end{array}$ \\
\hline Table 4. & 4 & Ethnicity & $\begin{array}{l}\text { Malay } \\
\text { Chinese } \\
\text { Indian } \\
\text { Others }\end{array}$ & $\begin{array}{l}9 \\
6 \\
2 \\
1\end{array}$ \\
\hline $\begin{array}{l}\text { Profile of interviewed } \\
\text { respondents (centre } \\
\text { operators) }\end{array}$ & 5 & $\begin{array}{l}\text { Year of the establishment } \\
\text { of the ageing centre }\end{array}$ & $\begin{array}{l}3-6 \text { years } \\
6-9 \text { years } \\
9 \text { years onward }\end{array}$ & $\begin{array}{l}5 \\
8 \\
4\end{array}$ \\
\hline
\end{tabular}

to males. The age of the elderly in the centres skewed towards 65 years and more, in the majority of centres. The monthly expense in 7 centres $(01,03,04,010,011,012$ and 017$)$ ranging from $\mathrm{RM} 15,000-20,000,5$ centres $(\mathrm{O} 2, \mathrm{O} 3, \mathrm{O} 6, \mathrm{O} 8$ and $\mathrm{O} 14)$ depicts monthly cost of RM20,000-40,000, whereas 6 centres (O5, O9, O13, O15, O16 and O18) incurred monthly expense of above RM40,000. The main income generation of the majority of the centres is from the customer's service fees. Regarding donations, the majority of the centres show no support in terms of donation except (O13 and O18). A total of 13 centres (O1, O2, O3, O4, O5, O7, O8, O11, O12, O15, O16, O17 and O18) reported nil for other activities involvement. However, the other five centres are involved in renting facilities and selling consumable medical items and nonmedical services (06, O9, O10, 013 and O14) for business survival. The service fee of all centres shows different packages depending upon the condition of elderly and services requirements, ranging from RM500 to RM6,000. The type of employment mostly skewed towards permanent and contractual. Regarding governmental support, the majority of the centres $(\mathrm{O} 1, \mathrm{O} 2, \mathrm{O} 3, \mathrm{O} 4, \mathrm{O} 5, \mathrm{O} 6, \mathrm{O} 7, \mathrm{O} 8, \mathrm{O} 9, \mathrm{O} 12, \mathrm{O} 14, \mathrm{O} 15$ and O18) reported that they are not receiving any government funding as they have applied for it but failed to get it. Regarding the main objective behind opening a centre, the majority of the participants stated passion, and some considered the elderly care as their responsibility. Below are the profile details of interviewed participants (Tables 5 and 6).

Table 7 above shows the profile of the second group of participants - caregivers. The details that disclose out of 15 participants, 5 belong to the age group of 25-31years, 4 belong to the age group 36- 40 years and 2 belong to the age group 40-45years, whereas another 4 belong to age group 45 onward. For the present study, five males and ten females were interviewed. Regarding qualification, nine participants have a diploma certification and six have a bachelor's degree. The majority of the participants skewed towards Malay ethnicity (7), followed by Chinese (4), Indians (2) and (2) other nationality. Regarding year of service, five of them have been working as a caregiver for three to six years, followed by four respondents working for nine years or more, another four working less than one year and two have been working between six and nine years. 


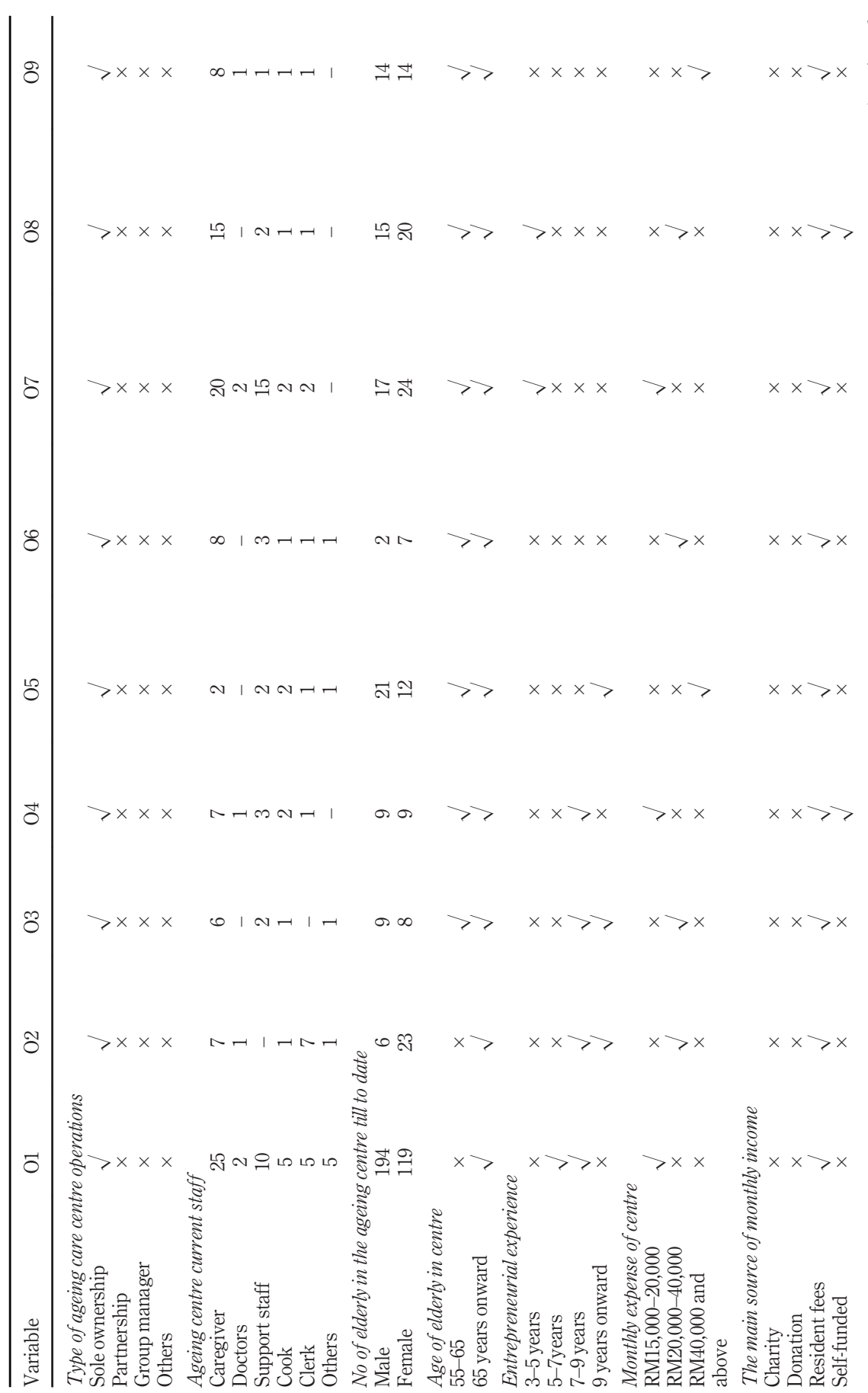

Exploring the facet of elderly care centre

23

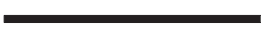

Table 5.

Profile of interviewed respondents (centre operators) 


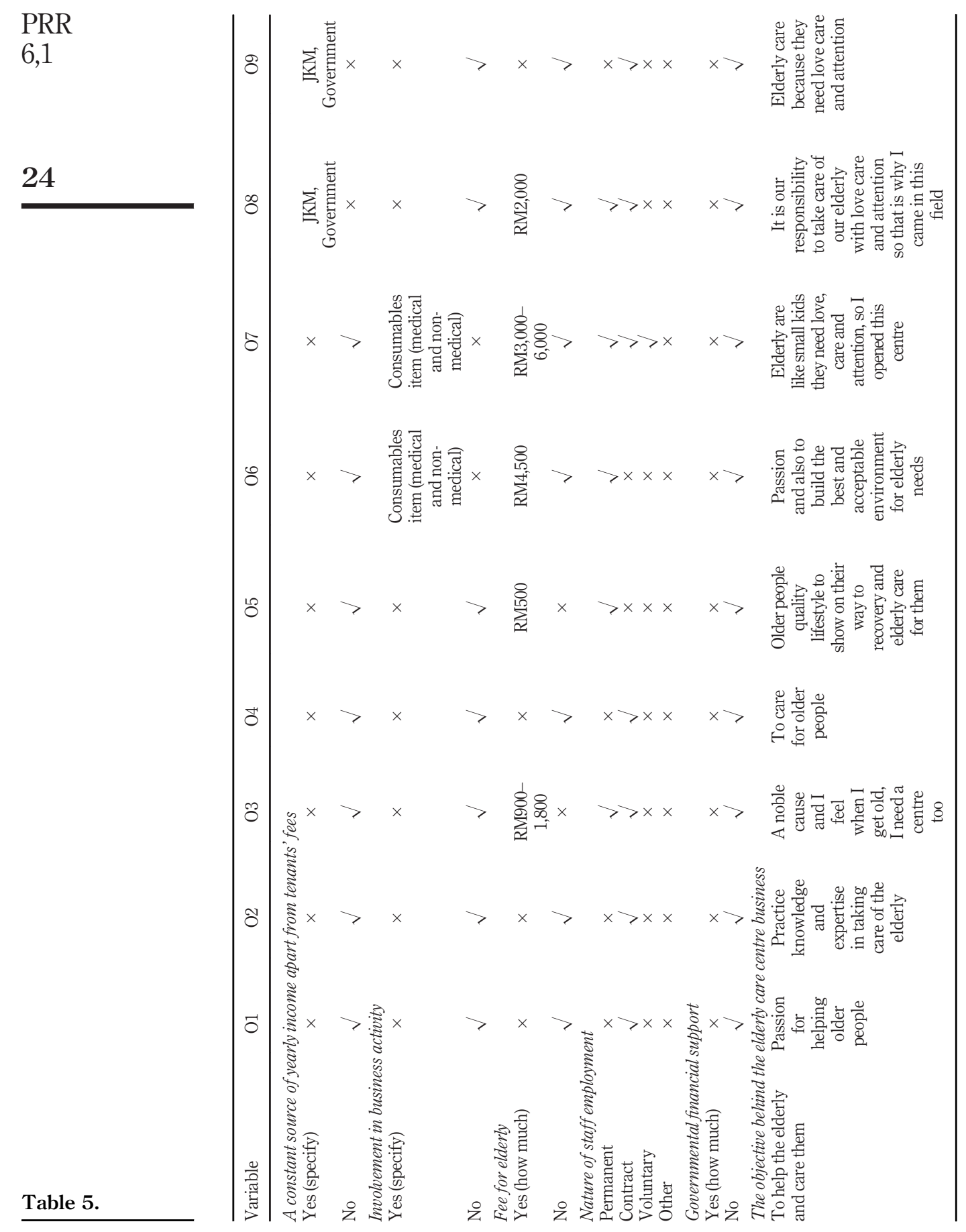




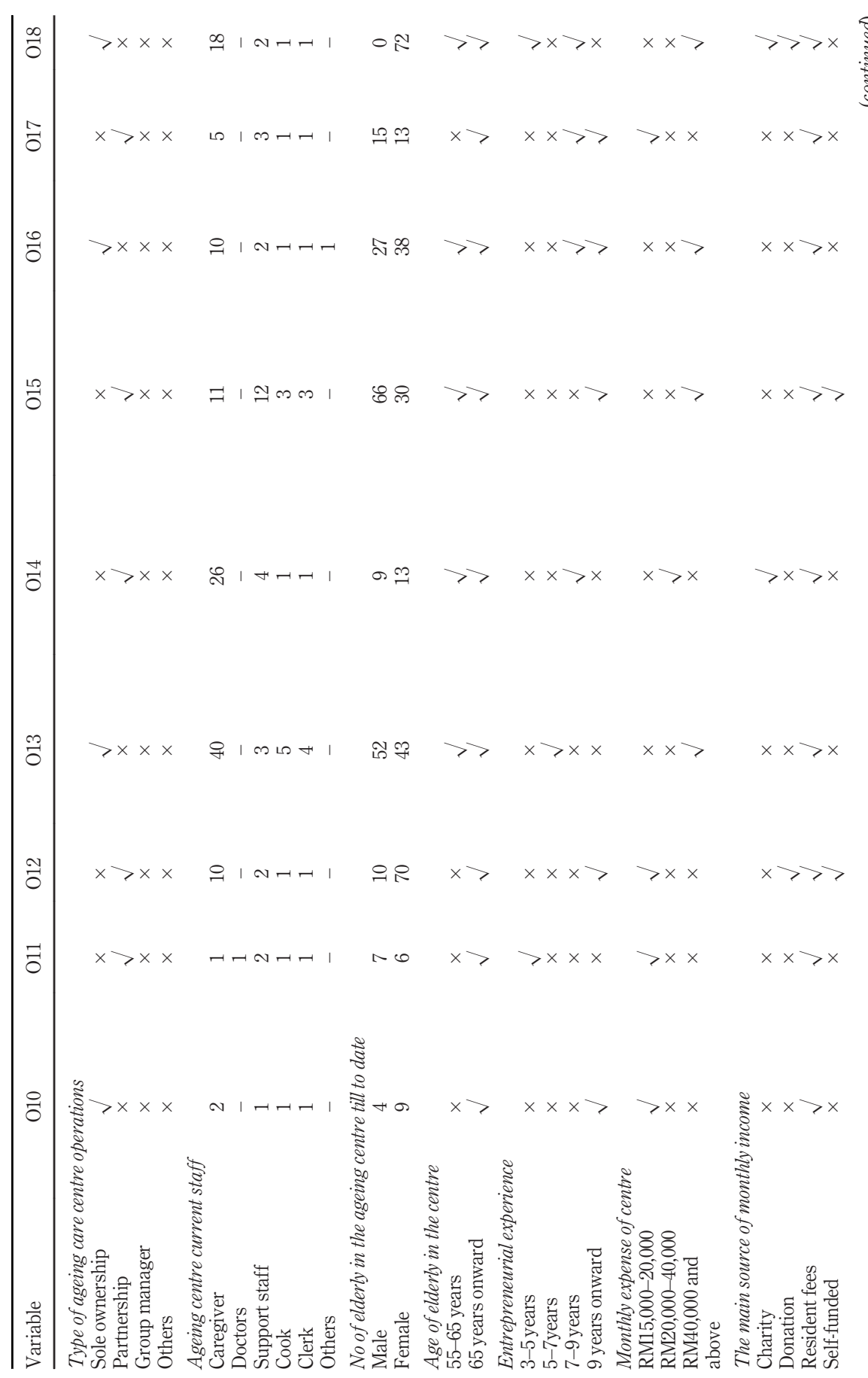

Exploring the facet of elderly care centre

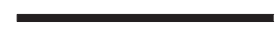

Table 6.

Profile of interviewed respondents (centre operators) 


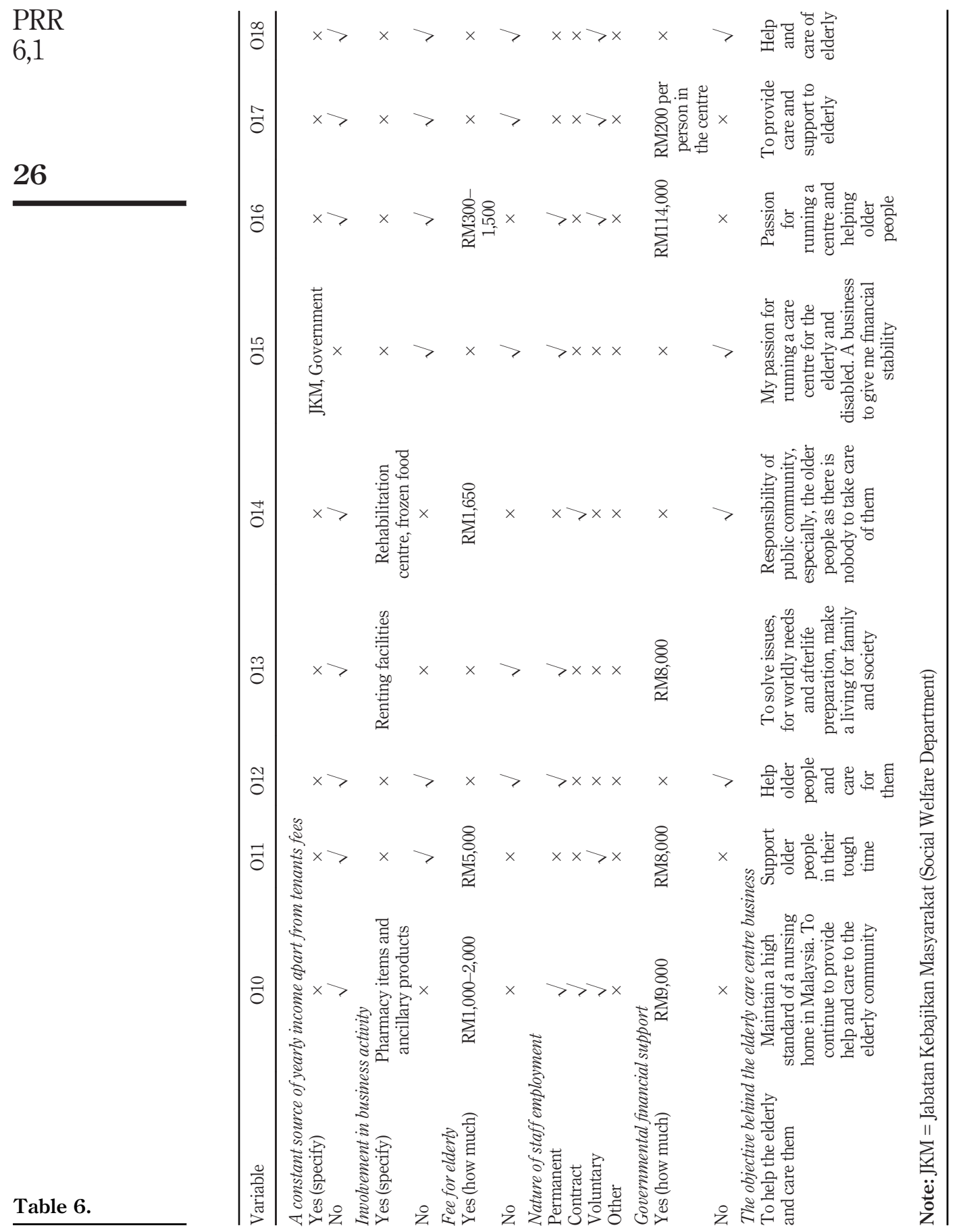




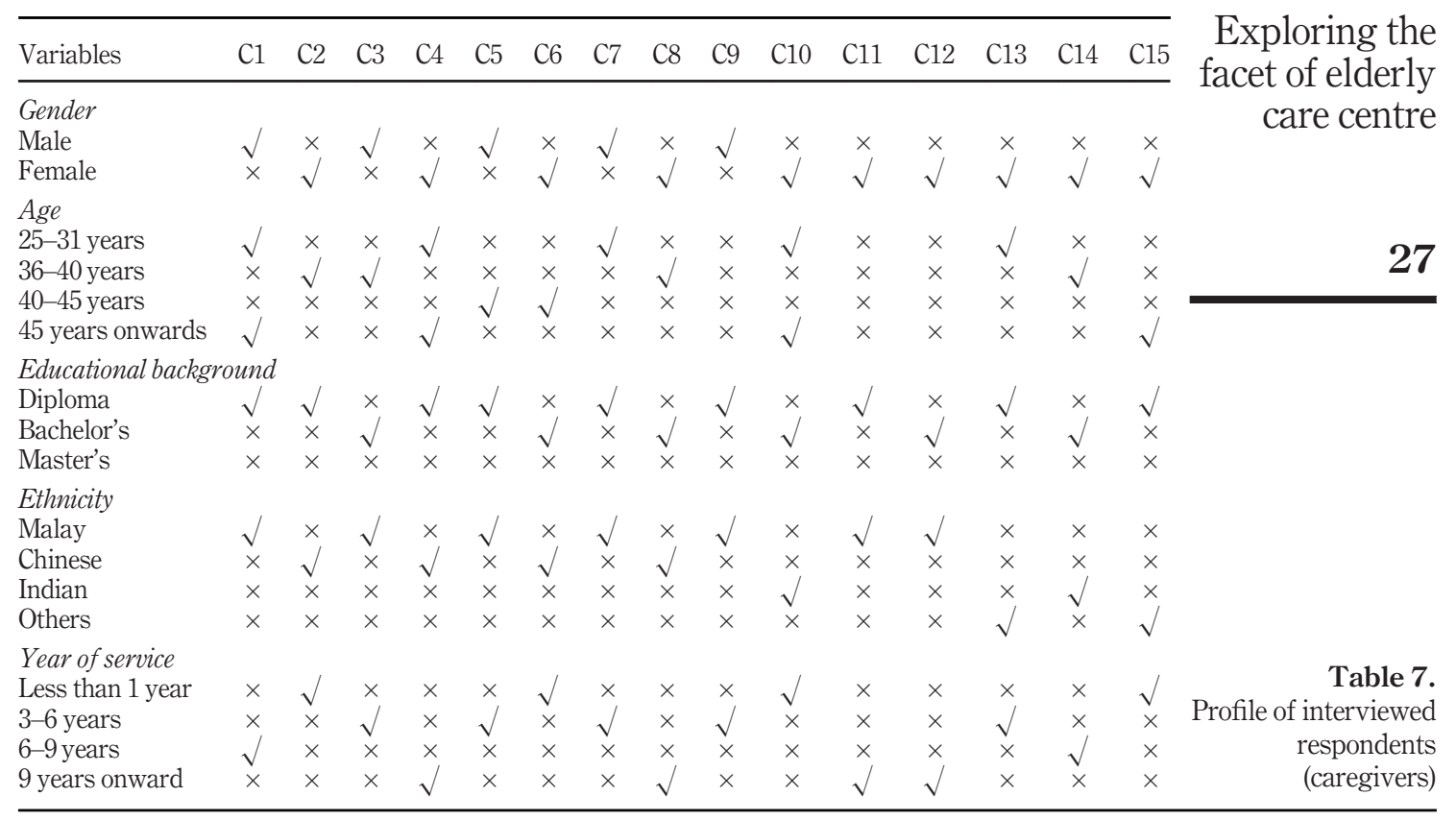

\section{Discussion}

The present study adopted the qualitative research strategy; interviews were conducted with the centres' operators and caregivers, to explore the demographics facet of Malaysian elderly care centres and issues and challenges confronted by the centre operators and caregivers. Hence, coded data from each of interviewed participant was cross-referenced with another participant to locate the similarities and dissimilarities among the participant's views in particular. Crotty (1998) stated that the continuous comparison results in lesser number of themes for a research question. Table 8 explains the generated themes from the transcribed interview under interview questions asked to the centres' operators.

Pertaining to $Q 1$ regarding any challenging situation while managing the centre, majority of the operators explained about staffing, funding and government support, and these findings are in line with previous findings (Meriam Syed Akil and Abdullah, 2014; Noor et al., 2020; Samad and Mansor, 2017). The feedbacks from the participants are stated below:

I feel like the main hindrance is to get the trained, passionate workers, because once we have them, it will be very easy to take care of the elderly for 24 hours a day since it needs workers with a big heart. The funding also is another obstacle, and we are not getting support from the government (Participant O11).

I am facing a lack of trained staff and funding; we are barely sustaining our business without any profit. We are using different ways to cover our operational cost. Staff retention is another issue because we have mostly young staff, and they become emotional sometimes and takes their decision haphazard (Participant O9).

Concerning to $Q 2$ regarding the solution of issues and problems related to managerial practices. The participants revealed about training and counselling, loans from friend and 
Have you ever come across any challenging situation while managing this centre?

\section{8}

How do you resolve issues and problems related to managerial practices, such as human resource and administrative works?

What type of marketing communication strategy do you practice? (e.g. website; social media, e.g. Facebook and Twitter; public relation activities; events; and advertisement)

How do you resolve the financial problems of the centre? Explain the strategies to solve the problem

What is your experience in managing this centre?

\section{Table 8.}

Generated themes
Themes

participants

Licensing issuance and renewal $\quad 17$

Staff training 16

No government support $\quad 15$

Less technology 13

Financial issues $\quad 17$

Initial funding $\quad 16$

Lack of trained staff $\quad 18$

Staff conflicts $\quad 14$

Elderly families issues $\quad 13$

Staff training $\quad 12$

Counselling of elderly families $\quad 14$

Orientation session $\quad 15$

Staff counselling $\quad 17$

A loan from family and friend circle $\quad 16$

Door to door marketing $\quad 11$

Patient record database (hard and soft) 13

Door to door counselling $\quad 15$

Orientation session $\quad 13$

Facebook 18

Website 18

Twitter 14

Advertisement 12

Loans from friends and family circle $\quad 17$

Small business $\quad 5$

Applied for government support $\quad 13$

Acceptance of donation (staple food or other $\quad 18$

items)

Funds from NGOs (sometimes) 11

Hectic 11

Struggling $\quad 16$

Difficult $\quad 15$

Demanding $\quad 17$

Heavy responsibility 18

family circle and marketing, as agreed by previous studies (Ariffin et al., 2017; Lam et al., 2018; Sharpe, 2011). One of the feedbacks from participant O6 is listed below:

I have faced staff retention issue, but we discussed with them, sorted out the issue by best possible solution because we cannot force them to work; yes, we counsel them if any issue arises. Besides, to get retained nurses is tough, because nurses once they get the opportunity of big hospitals, they move. We cannot stop them, and this is not that much career path for the nurses to come into the elderly centre. That is something that the government has to do, something in making elderly home care as an industry and opt it as a career path. (Participant O6)

Regarding Q3, type of marketing communication strategy adopted by the respondents are door to door counselling, Facebook, orientation session and the website, and these are in line with previous research studies (Noor et al., 2020; Tohit, 2012). Below is one of the feedbacks from participant O3: 
We did marketing by door to door and conducting sessions in mosques also, and orientation sessions in my centre for marketing. We have Facebook and website, but still, I think we need a marketing manager for proper marketing (Participant O3).

Concerning to $Q 4$ regarding how to tackle the financial problems, majority of the respondents revealed about small business, acceptance of donation (staple food and other items), funding from private sectors, followed by a request of government funding, which are also highlighted in several previous research studies (Meriam Syed Akil and Abdullah, 2014; Sharpe, 2011; Noor et al., 2019):

We applied for funding, but we have not received any support from JKM yet. People gave us donations in the form of furniture and kitchen utensils, and wet and dry items (Food supplies). We are trying to cut some cost from small business activity such as Rehabilitation centre and frozen food (Participant O14).

About Q5 regarding experience in managing the centre, majority of the participants considered it as challenging, and this finding is in line with previous research studies (Meriam Syed Akil and Abdullah, 2014; Rashid and Tahir, 2015; Beard, 2016). Some of the feedbacks from the participants are stated below:

My experience, I will say is very difficult, full of challenges, hard work and complications. I struggled a lot and worked day and night. Sometimes, my family was also neglected at that time. The biggest challenge I faced were in getting licensed and initial funding. I asked help from my family and friends circle (Participant O10).

My experience, well I will say was extremely challenging and complicated that at some stages, I thought to leave this work, but my passion for elderly care stopped me from taking such action. Yes, this centre is working now after many hardships and tough times I passed in terms of initiation to proper working, and up till now every day is a challenge (Participant O5) (Figure 1).

Table 9 demonstrates the generated themes from the transcribed interview under interview questions asked from centre caregivers.

Regarding Q1, the main reason(s) for taking up this position in this centre, the participants revealed about passion, part-time job, elderly care and no job as the reasons which are in line with previous research studies (Abudu-Birresborn et al., 2019; Minton and Batten, 2016; Rejeh et al., 2010):

My ambition is to work for the elderly and I feel good when I care for them, and secondly I have no job, so I started doing this job. I like to help older people (Respondent C4).

I saw older people had not cared well as they used to get ill, so I came into this job to help them and make them happy of this phase of life too (Respondent C11).

In relation to $Q 2$ about the major challenges caregivers face while dealing with the elderly, majority of respondents explained about aggressive patients, memory issues specifically dementia patients, full of stress environment, weak and improper management policies, long duty hours and lack of knowledge on elderly care. These findings are in tandem with past literature (Rejeh et al., 2010; Smeulers et al., 2014; Wang et al., 2018):

I feel like sometimes it has become very difficult to handle aggressive patient, and also those who forget that we have given them bath and breakfast, due to this forgetness they become annoyed and sometimes challenging to handle them (Respondent C8).
Exploring the facet of elderly care centre 


\section{PRR}

6,1

30

Figure 1.

Challenges faced by operators in elderly care centres
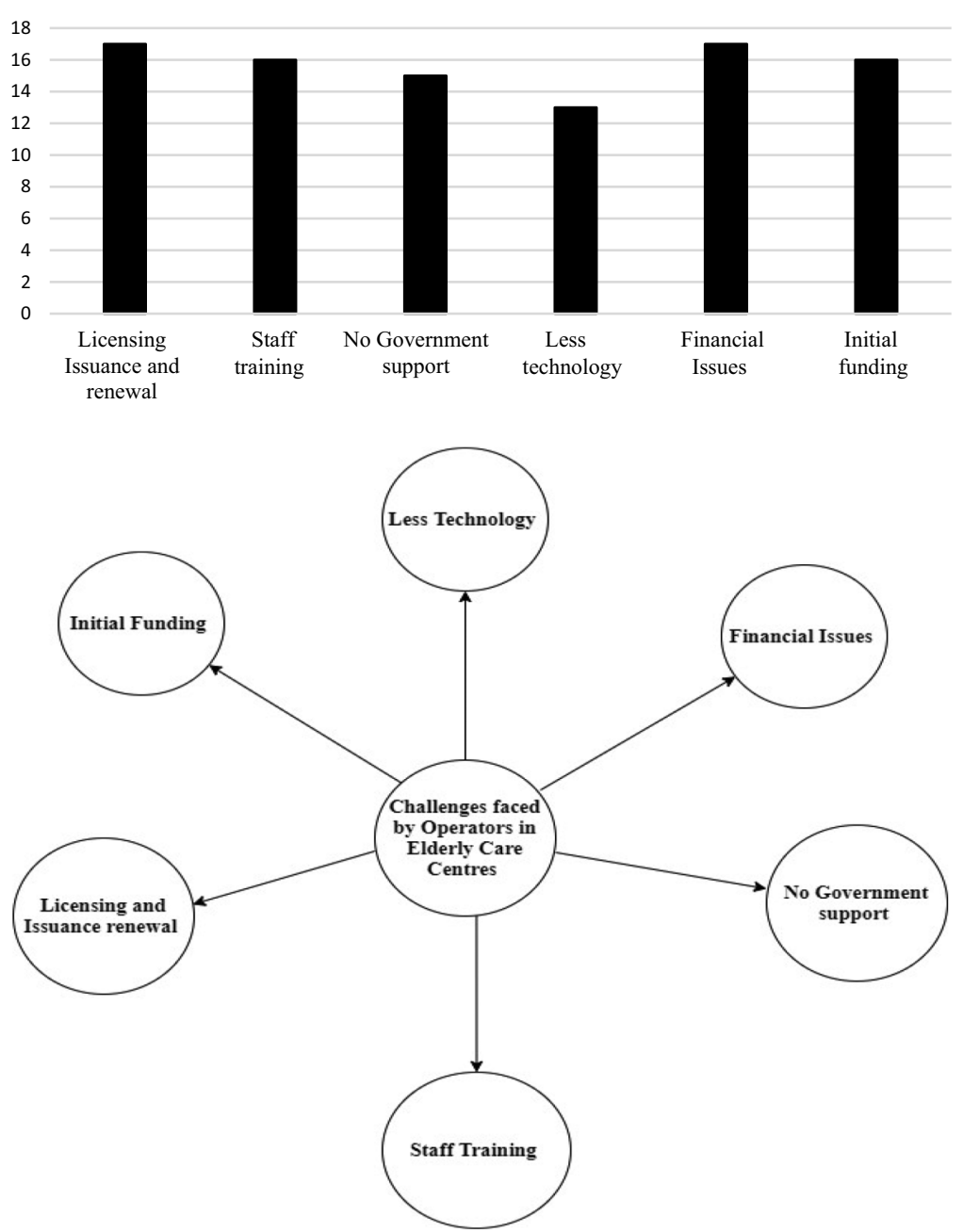

I think the bigger challenge is ignorance of how to deal and care for the elderly, and we need training and proper management policies related to the care of older people in the centre. I think we have to streamline this first. (Respondent C14).

Relating to Q3 about dealing with challenges of staff and management, the participants mentioned lack of privacy, tough schedule, management favouritism, communication gap, peer conflicts and less experienced staff and administration, which accede with past literature (Aghabarary and Nayeri, 2016; Rostami et al., 2019):

I think the admin should not practice favouritism; they must treat all staff equally because staff conflict increases by this and de-motivation also comes. We need to be treated equally by management (Respondent C3). 


\begin{tabular}{|c|c|c|c|}
\hline Interview question & Themes & No. of participants & xploring the \\
\hline $\begin{array}{l}\text { What is your main reason(s) for taking } \\
\text { up this position in this centre? }\end{array}$ & $\begin{array}{l}\text { Passion } \\
\text { Part-time job } \\
\text { Care for the elderly } \\
\text { Sake of money } \\
\text { Better future } \\
\text { No job }\end{array}$ & $\begin{array}{l}2 \\
5 \\
2 \\
3 \\
2 \\
1\end{array}$ & care centre \\
\hline $\begin{array}{l}\text { What are some of the major challenges } \\
\text { you face when dealing with the elderly? } \\
\text { Briefly explain each challenge }\end{array}$ & $\begin{array}{l}\text { Aggressive patients } \\
\text { Memory issues } \\
\text { Dementia patients } \\
\text { Stress } \\
\text { Improper management policies } \\
\text { Long hours duty } \\
\text { Lack of knowledge on elderly care }\end{array}$ & $\begin{array}{l}12 \\
11 \\
10 \\
14 \\
14 \\
12 \\
13\end{array}$ & \\
\hline $\begin{array}{l}\text { Have you faced any challenges when } \\
\text { dealing with the staff and management } \\
\text { throughout the course of work in this } \\
\text { centre? }\end{array}$ & $\begin{array}{l}\text { Lack of privacy } \\
\text { Tough schedule } \\
\text { Management favouritism } \\
\text { Communication gap } \\
\text { Peer conflicts } \\
\text { Less experienced staff and administration }\end{array}$ & $\begin{array}{r}10 \\
13 \\
12 \\
9 \\
8 \\
11\end{array}$ & $\begin{array}{r}\text { Table } 9 . \\
\text { Generated themes }\end{array}$ \\
\hline $\begin{array}{l}\text { What are your suggestions to improve } \\
\text { the centre's leadership, management } \\
\text { and operations etc.? }\end{array}$ & $\begin{array}{l}\text { Proper policies } \\
\text { Appropriate patients' assignment } \\
\text { Proper handing over } \\
\text { Weekly meetings with staff } \\
\text { Specialised knowledge of elderly care }\end{array}$ & $\begin{array}{l}13 \\
11 \\
14 \\
12 \\
14\end{array}$ & $\begin{array}{r}\text { from the transcribed } \\
\text { interview under } \\
\text { interview questions } \\
\text { asked from centre } \\
\text { caregivers }\end{array}$ \\
\hline
\end{tabular}

Regarding Q4 on the suggestions to improve the centre's leadership, management and operations, the participants stated that there should be proper policies, weekly meeting with staff, proper handing over and specialised knowledge of elderly care, which is badly needed in the centre, and these are in line with past research studies (Smeulers et al., 2014; AbuduBirresborn et al., 2019):

I feel like specialized knowledge for elderly care is missing, due to the management policies and leadership that are not that strong as it should be. Similarly, proper handing over procedures should be introduced (Participant C1).

I think that there should be meeting with staff weekly, and feedback and suggestions from staff should be listened, as they are in the front line with the elderly. Thus, the issues which the staff highlighted must be considered. The policies must be revised, keeping in view the suggestion of staff (Participant C11) (Figure 2).

\section{Implications for practice}

While keeping in view the challenges faced by centre operators and caregivers in elderly care centres in Malaysia at present, the following implications have been proposed to mediate the challenges and obstacles which caregivers and centres' operators are facing in elderly care centres:

- Government support in the form of funding is mandatory to all elderly care centres irrespective of public, private and centres that come under religious organisations. These centres are facing severe financial constraints because of the unavailability of funds and always encounter delay in elderly fees submission from elderly families. 


\section{PRR}

6,1

32
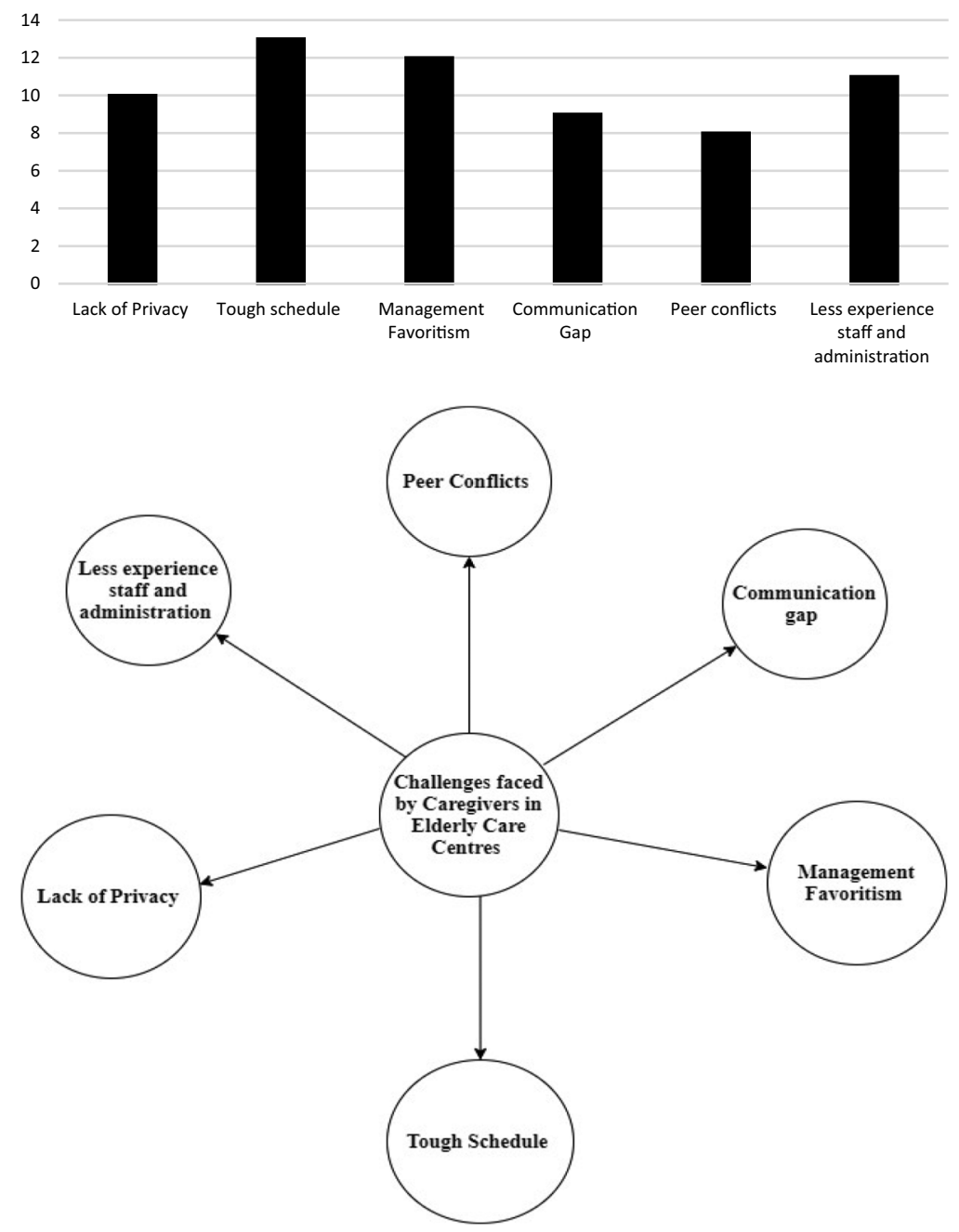

Figure 2.

Challenges faced by caregivers in elderly care centres

The annual funding from the government will help the centres to cut their operational cost to some extent.

- The licensing procedure should be streamlined with one window operation where officials should guide the operators regarding terms and conditions on the issuance and renewal of licenses. The proper licensing procedure may help to formalise the economy and secure the businesses.

- There is a need for a central geriatric training centre under the Ministry of Health and the elderly care centre's staff training must be considered mandatory from the geriatric training centre. It will minimise the issue of lesstrained staff. The staff training is very crucial as currently many staffs are immature and lack in patience and empathy, which is considered as the core 
element to be an aged care staff along with effective communication skills and positive attitude.

- The centres' operators need to attend training programs to improve their leadership skills and also refine their administrative skills. Thus, developing good leadership skills may benefit the whole centre. Management, finance and marketing pieces of training may help the entrepreneurs to re-strategise the original business process, time management, networking and strategic thinking.

- Management must follow the performance-based measures and avoid favouritism, and must communicate with staff frequently as well as praise them often. This practice will motivate the staff. The centres' operators must create a professional environment free from any kind of unfair treatment.

- The operational policies need to be revised containing the standard operating procedures, the hierarchy of organisation along with emergency procedures. It is imperative to have proper standard operating procedures (SOPs) of the centre, as it will help the staff to perform daily operations effectively. The SOP is a valuable business tool as it demonstrates the correct way to carry out an activity with a direction and proper guidance.

- Elderly families' cooperation is highly needed for the smooth functioning of these centres as most of the centre complained about the delay in fee submission and non-cooperative behaviour in terms of the frequent visit to their parents. The centre can only provide health supports to their parent, but the elderly still rely on families for emotional support. The families should cooperate in this regard as centre and elderly families may work together to save the ageing population from mental disorders, stress and trauma and make them ageing gracefully.

\section{Theoretical justification}

Resource-based view

The resource-based view (RBV) theory has become a dominant theoretical foundation in strategic management (Newbert, 2019; Stieglitz and Heine, 2007) and has been applied to strategic marketing as well (Morgan et al., 2006; Zahay and Peltier, 2008; Voola and O'Cass, 2010). According to Barney et al. (2011), the RBV originated from the work of the economist named Penrose (1959), who argued that "services yielded by resources are a function of the way in which they are used - exactly the same resource when used for different purposes or in different ways and combined with different types or amounts of other resources provides a different service or set of services". Penrose's (1959) arguments suggest that the uniqueness of an organisation is based on how the organisation combines its resources and capabilities. This theory attempts to answer the following question: what types of organisational capabilities lead to a sustainable competitive advantage (Vora et al., 2012). RBV explains how a firm attains a sustainable competitive advantage and superior performance. This theory provides that firms can perform effectively and attain the competitive advantage if they have better resources and have the abilities to use them to exploit the opportunities and outperform the competitors (Voola and O'Cass, 2010). Resources are not only considered as the internal production capabilities of the firms, but also serve as the abilities of the firm to get adjusted according to the environment. Resources may include the managerial capabilities to learn developing new resources or strategies to 
PRR

6,1

respond effectively to the external environment to attain a competitive advantage and superior performance (Ferna and Romero-mart1, 2010). The RBV theory describes that firms have a bundle of resources that possess certain specific characteristics that have the potential to provide a sustainable competitive advantage. Thus, more excellent managerial abilities and skills are required to deploy these resources that collectively produce better performance and returns (Mahoney, 1995). The ability of the firm to understand the market and response to market changes not only ensure the firm's survival in the competitive environment but also enhances the firm's performance. The core competencies of the firm may include risk-taking attitude and learning of new ideas for overcoming the external pressure. For attaining the superior firm performance, a certain amount of competence is required (Lumpkin and Dess, 1996). Based on the premises, the overall capabilities of the firm to develop internal resources by developing new strategies implement strategic orientations and continuously enhance the innovative capabilities of the firm, to respond to the external environment's demands that are the key to sustainable competitive advantage. Thus, the operator and caregiver, both are considered as strong pillars for smooth running of elderly care centres. As in year 2005, 7\% of the elderly population aged 60 years, which is expected to be doubled or $14 \%$ by the year 2028 . This situation is alarming and requires awareness in place of infrastructure and various facilities to look after the older population of Malaysia.

\section{Conclusion}

Elderly people are not considered prior in international policy development since ages. In recent years, because of drastic demographic changes in various countries worldwide, older people become significant in development agendas. This leads towards a new prototype of research on elderly care centre. In this regard, governments all across the world start to engage in the development of policies, to meet up the challenges faced in handling the ageing population, in both health and infrastructure matters. Noteworthy, the ageing population is a global phenomenon and has an impact (direct or indirect) on all human life traits. Hence, developed and developing countries must see the issue of ageing scientifically. Elderly home or old homes strategy plays a vital role to look after the Malaysian aged population in a more systematic order. Hence, a better support system for the elderly population in the form of well-equipped elderly care centres is needed. As the elderly population facilitated the nation in their prime and now, it is a compulsion on society to provide them proper care, attention and help. The present study reveals the demographic disguise of elderly care centres in Malaysia and challenges which caregivers and operators are facing while managing these centres. This study will help the policymakers to formulate specific strategies for elderly care centres, keeping in view the challenges confronted by front line custodians of ageing industry such as operators and caregivers. This practice will lead to active and graceful ageing in Malaysia. As this study is limited to 28 centres and involved the entrepreneurs (male and female), future studies may be conducted to add more centres throughout Malaysia and comparison of centres run by male and female entrepreneurs from different ethnicities can be done to get a holistic view of obstacles confronted by male and female entrepreneurs in ageing care centres.

\section{References}

Abudu-Birresborn, D., McCleary, L., Puts, M., Yakong, V. and Cranley, L. (2019), "Preparing nurses and nursing students to care for older adults in lower and middle-income countries: a scoping review", International Journal of Nursing Studies, Vol. 92, pp. 121-134, PMid: 30807890, doi: 10.1016/j.ijnurstu.2019.01.018. 
Advance Care Planning (2018), "Conversation about your future self and care management and finance", available at: www.agedcare.com.my/acgconcept $/ 0.2017 /$ july/caregiverpreneurs

Aghabarary, M. and Nayeri, N.D. (2016), "Nurses' perceptions of futile care: a qualitative study", Holistic Nursing Practice, Vol. 30 No. 1, pp. 25-32, PMid: 26633723, doi: 10.1097/ HNP.0000000000000128.

Amiri, M. (2018), "Problems faced by old age people”, The International Journal of Indian, Vol. 6 No. 3 , pp. 52-62.

Ariffin, A.S., Baqutayan, S.M.S. and Mahdzir, A.M. (2017), "Enhancing women entrepreneurship Exploring the facet of elderly care centre development framework: policy and institution gap and challenges in the case of Malaysia", Journal of Science, Technology and Innovation Policy, Vol. 3 No. 2.

Barney, J.B., Ketchen, D.J. and Wright, M. (2011), "The future of resource-based theory", Journal of Management, Vol. 37 No. 5, pp. 1299-1315, doi: 10.1177/0149206310391805.

Beard, J.R., Officer, A.M. and Cassels, A.K. (2016), "The world report on ageing and health", The Gerontologist, Vol. 56 No. Suppl 2, pp. S163-S166, PMid: 26994257, doi: 10.1093/geront/gnw037.

Bradburn, N.M., Sudman, S. and Wansink, B. (2004), Asking Questions: The Definitive Guide to Questionnaire Design - for Market Research, Political Polls, and Social and Health Questionnaires, John Wiley and Sons.

Bryman, A. and Bell, E. (2007), Business Research Methods, 2nd ed., Oxford University Press, New York, NY.

Burton, C. (2016), "Livability for all: the 2016 AARP age-friendly community survey of Tallahassee, Florida AARP members and residents age 50-plus", American Association of Retired Persons, available at: www.aarp.org/content/dam/aarp/research/surveys_statistics/liv-com/2016/2016afctallahassee-report-rc-liv-com.pdf (accessed 16 September 2016).

Creswell, J.W. and Poth, C.N. (2013), "Qualitative inquiry and research design: choosing among five approaches", available at: https://in.sagepub.com/enin/sas/qualitative-inquiry-and-researchdesign/book246896 (accessed 23 February 2019).

Creswell, J.W. (2003), Research Design: Qualitative, Quantitative, and Mixed Method Approaches, 3rd ed., Sage Publications, Inc, Thousand Oaks, CA.

Crotty, M. (1998), Foundations of Social Research: Meaning and Perspective in the Research Process, Allen and Unwin.

Department of Statistics Malaysia (2018), available at: www.dosm.gov.my/v1/ (accessed 1 August 2018).

Easterby-Smith, M., Thorpe, R. and Lowe, A. (1991), "Qualitative methods”, Management Research: An Introduction, pp. 71-115.

Fahey, T. (2003), "Quality of care for elderly residents in nursing homes and elderly people living at home: controlled observational study", BMJ, Vol. 326 No. 7389, pp. 580-580, doi: 10.1136/ bmj.326.7389.580.

Ferna, Z. and Romero-Mart, A.M. (2010), "Exploring corporate entrepreneurship in privatized firms", Journal of World Business, Vol. 45, pp. 2-8, doi: 10.1016/j.jwb.2009.04.008.

Forsyth, D.R. and Chia, Y.C. (2009), "How should Malaysia respond to its ageing society?", The Medical Journal of Malaysia, Vol. 64 No. 1, pp. 46-50.

Hall, E., Chai, W. and Albrecht, J.A. (2016), "A qualitative phenomenological exploration of teachers' experience with nutrition education", American Journal of Health Education, Vol. 47 No. 3, pp. 136-148, doi: 10.1080/19325037.2016.1157532.

Keyes, L. (2017), "Nurse entrepreneur trends", available at: www.nurseentrepreneur-network.com/ public/727.cfm (accessed 22 May 2017).

King, C., Rossetti, J., Smith, T.J., Raison, M., Gallegos, D., Gorman, R., Moscatel, S., Smyth, S. and Watson, J. (2019), "Effects of a mindfulness activity on nursing service 
PRR

6,1

staff perceptions of caring behaviors in the workplace", Journal of Psychosocial Nursing and Mental Health Services, Vol. 57 No. 11, pp. 28-36, doi: 10.3928/0279369520190626-01.

Lam, H.R., Chow, S., Taylor, K., Chow, R., Lam, H., Bonin, K., Rowbottom, L. and Herrmann, N. (2018), "Challenges of conducting research in long- term care facilities: a systematic review", BMC Geriatrics, Vol. 18 No. 1, pp. 1-11.

Leng, O.T.S., Khan, S., Vergara, R.G. and Khan, N. (2016), "Policies and protections for ageing society in Malaysia", Journal of Southeast Asian Research, doi: 10.5171/2016.974366.

Lumpkin, G.T. and Dess, G.G. (1996), "Linking two dimensions of entrepreneurial orientation to firm performance: the moderating role of environment and industry life cycle", Journal of Business Venturing, Vol. 9026, pp. 429-451.

Mahoney, J.T. (1995), "The management of resources and the resource of management", Journal of Business Research, Vol. 33 No. 2, pp. 91-101, doi: 10.1016/0148-2963(94)00060-R.

Meriam Syed Akil, S. and Abdullah, S. (2014), "Challenges in managing elderly care centres in Malaysia”, International Journal of Arts and Sciences, Vol. 07 No. 3, pp. 1944-6934.

Merriam, S.B. (2009), Qualitative Research: A Guide to Design and Implementation, Jossey-Bass.

Miles, M. and Huberman, A.M. (1994), Qualitative Data Analysis, Sage Publications, Beverly Hills, CA.

Minton, C. and Batten, L. (2016), "Rethinking the intensive care environment: considering nature in nursing practice", Journal of Clinical Nursing, Vol. 25 Nos 1/2, pp. 269-277, PMid: 26769214, doi: 10.1111 jocn.13069.

Morgan, N.A., Vorhies, D.W. and Schlegelmilch, B.B. (2006), "Resource - performance relationships in industrial export ventures: the role of resource inimitability and substitutability 25 ", Industrial Marketing Management, Vol. 35 No. 5, pp. 621-633, doi: 10.1016/j.indmarman. 2005.05.018.

Moustakas, C. (1994), Phenomenological Research Methods, Sage, Thousand Oaks, CA.

Newbert, S.L. (2019), "Empirical research on the resource-based view of the firm: an assessment and suggestions for future research", Strategic Management Journal, Vol. 28 No. 2, pp. 121-146, doi: $10.1002 /$ smj.573.

Noor, S., Isa, F.M., Nor, L.M. and Ahmed, E.C. (2019), "Identifying the current trends and challenges of ageing care centres in Malaysia", International Review of Social Science, IRSS, Academy of IRMBR, Vol. 7 No. 7, ISSN 2309-0081.

Noor, S., Isa, F. and Mohd, L. (2020), "Sains Humanika ageing care Centre women entrepreneur: a silver bullet for ageing tsunami in Malaysia”, Sains Humanika, Vol. 1, pp. 51-62.

Normala, R., Azlini, C., Nurul, M. and Lukman, Z. (2014), "The prevalence of depression and its risk factors among Malay elderly in residential care", American Journal of Applied Sciences, Vol. 11 No. 9, pp. 1456-1462, doi: 10.3844/ajassp.2014.1456.1462.

Penrose, E. (1959), Theory of the Growth of the Firm, Basil Blackwell, London.

Phua, K.H., Yap, M.T. and Goh, L.G. (2019), “Ageing in Asia: contemporary trends and policy issues”, available at: http://search.ebscohost.com/login.aspx?direct=true\&scope=site\&db=nlebk\&db= nlabk\&AN=2158050

Rashid, A. and Tahir, I. (2015), "The prevalence and predictors of severe depression among the elderly in Malaysia", Journal of Cross-Cultural Gerontology, Vol. 30 No. 1, pp. 69-85.

Rejeh, N., Heravi-Karimooi, M. and Foroughan, M. (2010), "The needs of hospitalized elderly patients: a qualitative study", Iranian Journal of Ageing, Vol. 5 No. 1.

Rostami, S., Esmaeali, R., Jafari, H. and Cherati, J.Y. (2019), "Perception of futile care and caring behaviors of nurses in intensive care units”, Nursing Ethics, Vol. 26 No. 1, pp. 248-255, PMid: 28481130, doi: 10.1177/0969733017703694. 
Saldana, J. and Omasta, M. (2016), "Qualitative research: analyzing life”, Sage Publication, available at: books.google.com.my/books?id=4_o0DQAAQBAJ\&printsec=frontcover\&dq=Qualitative+ Research + Analysing + Life + Johnny + Saldana ++ Citation\&hl=en\&sa=X\&ved=0ahUKEwj t762ess7oAhUyDgGHZXzBgUQ6AEIKDAA\#v=onepage\&q=Qualitative $\%$ 20Research $\%$ 20Analysing\%20Life\%20Johnny \%20Saldana \%20\%20Citation\&f=false (accessed 19 December 2016).

Exploring the facet of elderly care centre

Samad, S. and Mansor, N. (2017), "Population ageing and social protection in Malaysia", Malaysian Journal of Economic Studies, Vol. 50 No. 2, pp. 139-156, available at: https://mjes.um.edu.my/ article/view/2873

Selvaratnam, D.P. (2009), "Effects of increased life expectancy in Malaysia”, 4th Malaysian National Economic Conference, Universiti Kebangsaan Malaysia, Kuantan, Pahang, 2-4 June, pp. 305-315.

Sharpe, A. (2011), "Is ageing a drag on productivity growth? A review article on ageing, health and productivity: the economics of increased life expectancy", International Productivity Monitor, No. 21, pp. 82-94, available at: https://ideas.repec.org/a/sls/ipmsls/v21y20115. html

Smeulers, M., Lucas, C. and Vermeulen, H. (2014), "Effectiveness of different nursing handover styles for ensuring continuity of information in hospitalised patients", The Cochrane Database of Systematic Reviews, No. 6, p. Cd009979, PMid: 24957503, doi: 10.1002/14651858. CD009979.pub2.

Soong (2016), "Newsletter of the national council of senior citizens organisations Malaysia (NACSCOM)", Vol. 32, Suara Kanan KDN NO PP 10706/09/2008(020548), Printer: Print Wizard Sdn Bhd No. 9, Jalan 17/45, 46400, Petaling Jaya, Selangor Darul Ehsan, Malaysia. Tel: 03-7956 2600.

Stieglitz, N. and Heine, K. (2007), "Innovations and the role of complementarities in a strategic theory of the firm”, Strategic Management Journal, Vol. 28 No. 1, pp. 1-15, doi: 10.1002/smj.565.

Tohit, N., Browning, C.J. and Radermacher, H. (2012), "We want a peaceful life here and hereafter: healthy ageing perspectives of older Malays in Malaysia”, Ageing and Society, Vol. 32 No. 3, pp. 405-424, doi: 10.1017/s0144686x11000316.

Ursulica, T.E. (2016), "The relationship between health care needs and accessibility to health care services in Botosani County- Romania”, Procedia Environmental Sciences, Vol. 32, pp. 300-310, doi: 10.1016/j.proenv.2016.03.035.

Vannucci, M.J. and Weinstein, S.M. (2017), "The nurse entrepreneur: empowerment needs, challenges, and self-care practices", Nursing: Research and Reviews, Vol. 7, pp. 57-66, doi: 10.2147/NRR. S98407.

Voola, R. and O'Cass, A. (2010), "Implementing competitive strategies: the role of responsive and proactive market orientations", European Journal of Marketing, Vol. 44 Nos 1/2, pp. 245-266, doi: $10.1108 / 03090561011008691$.

Vora, D., Vora, J. and Polley, D. (2012), “Applying entrepreneurial orientation to a medium sized firm”, International Journal of Entrepreneurial Behavior and Research, Vol. 18 No. 3, pp. 352-379, doi: 10.1108/13552551211227738.

Wang, Y.Y., Wan, Q.Q., Lin, F., Zhou, W.J. and Shang, S.M. (2018), "Interventions to improve communication between nurses and physicians in the intensive care unit: an integrative literature review", International Journal of Nursing Sciences, Vol. 5 No. 1, pp. 81-88, PMid: 31406806 PMCid: PMC6626231, doi: 10.1016/j.ijnss.2017.09.007.

World Population Ageing (2019), "World population ageing 2019 highlights”, doi: 10.18356/9df3 caed-en.

Zahay, D.L. and Peltier, J. (2008), "Interactive strategy formation: organizational and entrepreneurial factors related to effective customer information systems practices in B2B firms", Industrial Marketing Management, Vol. 37 No. 2, pp. 191-205, doi: 10.1016/j. indmarman.2006.10.004. 
PRR

6,1

38
Zivin, K., Wharton, T. and Rostant, O. (2013), "The economic, public health, and caregiver burden of late-life depression", Psychiatric Clinics of North America, Vol. 36 No. 4, pp. 631-649, doi: 10.1016/ j.psc.2013.08.008.

\section{Further reading}

Barney, J. (1991), "Firm resources and sustained competitive advantages", Journal of Management, Vol. 17 No. 1, pp. 99-120.

World Population Prospects - Population Division - United Nations (2019), available at: https:// population.un.org/wpp/Download/Standard/Population/ (accessed 2020-04-05).

\section{Corresponding author}

Shaista Noor can be contacted at: shaistanoor25@gmail.com

For instructions on how to order reprints of this article, please visit our website: 